\title{
The experience of hospitalized children regarding their interactions with nursing professionals ${ }^{1}$
}

\author{
Ana Lucía Noreña Peña² \\ Luis Cibanal Juan ${ }^{3}$
}

\begin{abstract}
The aim of this study is to describe the experience of children in their interactions with nursing professionals while in hospital. It is a qualitative study supported by the critical incident technique. Data was collected through participant observation and semi-structured interviews with thirty hospitalized children and teenagers between 8 and 14 years old. The results showed that children positively valued nursing care at the hospital and recognized that interactions with nursing staff included social and emotional factors. It is concluded that communication established with children plays a fundamental role to comprehend their experiences while in hospital. Therefore, nurses need to evaluate their strategies and relational skills used to interact with children at the hospital.

Descriptors: Child Hospitalized; Nursing Care; Nurse Patient-Relations.
\end{abstract}

\footnotetext{
${ }^{1}$ Paper extracted from Doctoral Dissertation "La experiencia del niño hospitalizado en el encuentro comunicativo con los profesionales de enfermería", presented to Universidad de Alicante, Spain.

2 RN, Ph.D. in Nursing, Assistant Professor, Departamento de Enfermería, Universidad de Alicante, Spain. E-mail: ana.norena@ua.es. ${ }^{3}$ RN, Psychologist, Ph.D. in Psychology, Full Professor, Departamento de Enfermería, Universidad de Alicante, Spain. E-mail: luis.cibanal@ua.es.
}

Corresponding Author: Ana Lucía Noreña Peña Universidad de Alicante. Departamento de Enfermería Campus de Sant Vicente del Raspeig E-03080 Ap. 99, Alicante, España

E-mail: ana.norena@ua.es 


\section{A experiência de crianças hospitalizadas sobre sua interação com os profissionais de enfermagem}

O objetivo deste estudo foi descrever a experiência da criança na interação com os profissionais de Enfermagem, durante a internação hospitalar. Trata-se de estudo qualitativo, fundamentado na técnica do incidente crítico. A coleta de dados realizouse através da observação participante e de entrevistas semiestruturadas, com trinta crianças e adolescentes hospitalizados, tendo de 8 a 14 anos de idade. Os resultados mostram que as crianças avaliam positivamente o cuidado de Enfermagem no hospital, e reconhecem que as interações com os profissionais dessa área abrangem conteúdo afetivo e social. Conclui-se que a comunicação estabelecida com as crianças desempenha papel fundamental na compreensão que conseguem a respeito da experiência hospitalar, sendo necessária a avaliação das estratégias de Enfermagem, bem como das habilidades relacionais usadas para interagir com as crianças, no hospital.

Descritores: Criança Hospitalizada; Cuidados de Enfermagem; Relações EnfermeiroPaciente.

\section{La experiencia de los niños hospitalizados acerca de su interacción con los profesionales de enfermería}

El objetivo de este estudio es describir la experiencia del niño en la interacción con los profesionales de enfermería durante su estancia hospitalaria. Se trata de un estudio cualitativo fundamentado bajo la técnica del incidente crítico. La recolección de los datos se realizó mediante la observación participante y entrevistas semiestructuradas a treinta niños y adolescentes hospitalizados, con edades comprendidas entre 8-14 años. Los resultados muestran que los niños valoran positivamente el cuidado de enfermería en el hospital y reconocen que las interacciones con los profesionales de enfermería abarcan todo un contenido afectivo y social. Se concluye que la comunicación que se establece con los niños juega un papel fundamental en la comprensión que elaboran de la experiencia hospitalaria, por tanto es necesario en enfermería evaluar las estrategias y habilidades relacionales empleadas para interactuar con los niños en el hospital.

Descriptores: Niño Hospitalizado; Cuidado de Enfermería; Relaciones EnfermeroPaciente.

\section{Introduction}

Interpersonal relations and effective communication with patients are determinant factors of nursing care quality $^{(1)}$. Relations with nursing professionals are especially important when involving children, due to the fact that pediatric patients have needs that are very distinct from adults' needs, as a result of their limited ability to adapt to the hospital environment ${ }^{(2-3)}$.

One factor influencing children's general wellbeing is the meaning families and the children themselves attribute to hospital stimuli. Affect, therapeutic accompaniment and empathic relations are elements that determine the children's emotional conditions and affect their understanding about the processes they experience. In fact, the children and their families' perception about the relations with the nursing staff condition the responses to care ${ }^{(4-5)}$. For nursing researchers, communication with children is a challenge, turning it into a more sensitive and complex task than communication established with adult patients. This interrelation is necessarily conditioned by the child's age, cognitive skills, behaviors, physical and psychological condition, disease stage and treatment response ${ }^{(6)}$. It is proposed that, to improve knowledge on the component aspects of nurse-child-family interaction, studies 
are required that value the behaviors of each of the stakeholders involved, describe the factors intervening in this process and go deeper into the contents and structure itself of the interaction at certain times and in certain care circumstances ${ }^{(7)}$.

Thus, to get to know what factors influence or facilitate the relation established between the nursing staff and the hospitalized child, this study is proposed with the following aims: to describe the children's experience when interacting with nursing professionals during their hospital stay and to identify what behaviors nursing professionals adopt can influence the minors' psychosocial wellbeing.

\section{Methodological approach}

This is a qualitative study. The theoretical frameworks are: symbolic interactionism and constructivism. Symbolic interactionism helps to understand communication as social interaction and as a process in which people can exert mutual influence(8). Constructivism, in turn, permits understanding how the children construct reality and, in function of this reality, establish relations and act. At the methodological level, the critical incident technique guided data collection, which allows researchers to identify those situations and behaviors that are exerting significant influence in an activity. As a result, in turn, the positive or negative nature of certain conducts under analysis can be explained, establishing their possible consequences(9). This technique has been documented as a method that permits inquiries about topics emerging in the interaction, in care, in nursing activities and processes. It is useful to identify aspects that affect service quality ${ }^{(10)}$.

To collect the data, 30 children were interviewed, between 8 and 14 years of age. In total, 17 girls and 13 boys participated. Minors with different diagnoses participated, in the following specialty areas: neurosurgery, traumatology and surgery (majority in the postoperative phase). The participants' selection for the interviews is theoretical and intentional. Thus, the following inclusion criteria were established: minor hospitalized for more than 4 days, without pain (at the moment of the interview); and exclusion criteria: minor with cancer diagnosis or impaired cognitive function.

The research was accomplished at the pediatrics services of a University Hospital in Alicante-Spain. Its development took 22 months. Fieldwork started in the first half of 2006 and the final data were collected in the first term of 2008. Data were collected in two phases, in order to achieve theoretical sampling and data saturation. Participant observation and semistructured interview strategies were used. In total, 30 interviews were held and 198 hours of participant observation. The interviews were audio recorded, literally transcribed and took between 19 and 38 minutes. During these, questions were asked about themes related to the child's valuation of the interaction the nurse establishes, especially when giving information or explaining care themes to the children and their families and when they perform some procedures. Observations, in turn, were registered in a field diary and were aimed at contextualizing the reasons why and the particularities of nursing professionals' interactions with the children and their families. This study received approval from the institutional review board at the hospital institution where it was developed. Both the children and their parents received the informed consent term, in which they accepted to participate voluntarily. In addition, in the descriptions used in the interviews, to identify the subjects, fictitious names are used that do not correspond to the originals.

Data analysis was performed simultaneously with information collection. The analysis focused on 251 code forms and 228 pages of data, and Atlas-ti software version 5.0 was used to analyze the relations among the categories. Observations and interviews were coded separately, and later compared and contrasted. This permitted finding conceptual similarities between what was observed and what the informants had expressed. Throughout this coding process, all data were examined in comparison with bibliographic findings, seeking for category saturation and validation of relations. The way the categories were named follows the theoretical sequence of the critical incident technique: situationbehavior-consequence. It should be taken into account that, in this research, the child's interrelation with nursing professionals was analyzed as a study situation or phenomenon. Hence, behaviors (Communication) are related with the stakeholders' distinct attitudes and, finally, consequences are considered as children's experiences with the interaction. Thus, data analysis was conducted in view of the following criteria: reading and identification of the component elements of the critical incidents according to the children's reports and contrasts with observations, grouping of distinct incidents according to similarities in contrast with the bibliography and, finally, description and construction of emergent categories. 


\section{Results}

The following categories emerged: the child's behavior in the relational dimension, the nurse's behavior in the relational dimension, the child's experience: encounter with nursing. Within the sub-categories, the children's perceptions, feelings and demands regarding the relation with the professionals are described. To validate the category concepts, texts transcribed from the interviews and field diary notes are used, granting credibility and veracity to the study ${ }^{(11)}$.

\section{The child's behavior in the relational dimension}

\section{Gratitude for feeling safe}

The children declare they are satisfied with and grateful for the care they received at the hospital. They attribute special value to the safety the nursing staff grants them: I don't see any problem here, I'm well and the nurses always come to see me, they tell me things that make me feel safe and it seems good to me and that's why I behave well with them ...(E27,15). This example reveals that, when they feel supported and protected, the children improve their care responses. In turn, they manifest their gratitude towards nursing at certain times. To give an example, they thank the professionals when the procedure finishes, when they respond to their request or call, after a visit, among others. They attempt to demonstrate their acknowledgements through gifts when they are discharged or through visits to the services after their recovery: I wanted to say goodbye together with my mother and give them a gift, thank them, as I was going I wanted to do that. Because they'll feel good that I do that $(E 15,19)$. The fact that children demonstrate their gratitude for care is related to their personality type. Some children are more open when bonding and others are not. Different factors can explain this situation: the acute stress they face, the fears they assume when relating with elderly people and people representing authority, the learning they gain about how to behave when relating with adults, or the motivating influence significant relatives exert on this aspect(12).

The role of the child in the nurse-family relation

The children distinguish when the nursing professional starts communicating with the family and in what aspects they are involved or not. What is not clear to them at times is the role they play in the interaction; they do not know if they are listeners, participants or observers: Because about that, about the care I need here, they talk more with my mother and they don't tell me anything. Nevertheless I don't say anything, I limit myself to being there $(E 11,4)$. The children not rarely turn into observers of what the health professionals communicate to their relatives. Their attitude towards this position of observers is to be attentive to events or to keep waiting. Therefore, the children acknowledge that communication among adults is more valid(13).

In their discourse, in turn, the children recreate how adults address themes related to their health with their family: They talk a lot with my mother. They come and are always telling her things, I understand what they are saying: about how the wound is going, if there's more liquid or not, they explain. And my mother soon tells me what they say. But they don't talk much either about these things (E20). As observed in this statement, the children identify the way the nursing professional establishes communication with the family. In this sense, each professional responds to the relation with the children and their families according to the skills and strategies (s)he has developed through their clinical practice for patient communication purposes ${ }^{(14)}$.

\section{The professional's behavior}

Playful conversations and pranks

These are conversations with different goals. One is to entertain and distract the child during procedures or medical reviews, and the other is related with the intent on showing empathy to the child. To give an example, nursing professionals propose themes or joke about themes like: the child's favorite soccer team, the games, leisure activities, among others: So, they saw me playing cards and told me that they wanted to play with us ... $(E 2,10)$. These comments establish the base to extend the conversation, influence the minor's mood and permit the child's greater receptiveness towards the therapeutic activities.

Stimulating laughing and joy is an important factor for children's healthy growth and development and stimulates positive behaviors, besides learning and social interaction ${ }^{(15)}$. The children's descriptions reveal that pranks are a fundamental component at the relational level. To give an example, some of these can contain a burlesque tone. For the children, mockery is a synonym of fun, they enjoy sharing a pleasant time: I was eating, a nurse comes in and jokes: your eyes look like a frog and I tell her that I'm not a frog and she told me that it was a joke (laughs) (E14, 26).

Other pranks simply contain a funny tone. Most of these happen spontaneously, with a view to the 
child's entertainment, and are used as a way of being empathic with the minor: They came and said and asked me if I was Arturo, I said that no and they told me that I wouldn't get out of there until Arturo came (laughs) (E11, 17). Joking comments also occur during procedures, like wound dressing for example, relieving the minor's tension and anxiety towards the procedure: Yes, there are two girls, yes, nurses, who say things and I laugh. They come to cure me and say that they're going to carve me (points to the abdominal region) (laughs) $(\mathrm{E} 4,8)$. This type of interactions in communication with the children obviously entails therapeutic benefits. Humor and laughter are resources used as a tool of empathy and effective distraction ${ }^{(16)}$. The children value this stimulus positively and interpret it as a sign of encouragement for their mood.

\section{The social encounter. Family empathy skills}

The children highlight the way the nursing professionals treat their parents and the relation reached between both as a positive aspect. According to them, when professionals talk about situations related to daily and social themes, this expresses proximity and empathy. The children are influenced when they perceive that the nursing professionals create a climate of friendship with their parents: So, they come here, start talking to my mother, they say funny things. They talk to her about clothes and everything, about what she's sewing. They tell her that she does it very well, that she sews very well, that they like it $(\mathrm{E} 5,5)$. This approach with the parents or relatives is also enhanced when the nursing professionals participate in some anecdotic or playful situation in the family environment: Yes. Like the other day, on my mother's birthday, she came here with a pie and the nurse was with us $(E 2,29)$. Through the above, the child takes into account the relation of sympathy or antipathy perceived at certain times. The relation the nursing staff establishes with their parents or significant adults conditions the children's concept of nursing care quality.

\section{Effective mediation. Offering an identification model}

In the interaction, the nursing professionals offer identification models. These are linguistic resources, such as: anecdotes or personal stories. These elements act as distractors and decrease the child's anxiety, reinforcing empathy in the nursing-child relation. It is interesting to witness that the children recall storytelling or reports as a positive situation during therapeutic interventions: I liked it that she told me a story. When she was small, she gained sweets in return for the vaccines and she got a very big one that made her all feverish and she couldn't sit for days, it hurt so much. You know, when one of them was a child he was scared of those things, and which hurt and everything and you felt bad, but it was just for a while (E6, 40). As the report proves, histories play the role of cognitive referents the child uses for support to understand reality. It is easier for the minors to understand the situations they experience if adults give them examples of how to face them: it seemed special to me that the nurse asked what had happened to me and I told her that I had appendicitis, and she told me that she had peritonitis when she was 14 years old and that she felt very bad. It struck me to see that these people also have these diseases $(\mathrm{E} 8,27)$. Offering identification models through histories or oral reports makes it easier for the minors to identify those aspects that constitute certain situations, exercising their intelligence. As Erickson and Piaget present, they manage to achieve the adequate behavior, understand successes and identify values in accordance with their development phase ${ }^{(17)}$

\section{The child's experience. Encounter with nursing}

Affective bonds: acknowledgement of therapeutic accompaniment

The children argue that one way of showing them empathy is when one manifests interest in their health condition. According to them, nursing professionals achieve this through their daily visits, to know how they are doing: It's usually in the morning that they ask me how I am doing, if I'm well, how I'm feeling, always questions. Sometimes they are more sympathetic and I like it (E22, 64). This short interaction turns into a determinant factor of the children's perception about the attitudes nursing assumes in care delivery. They interpret constant questions about how they are doing as a sign of accompaniment. The children particularly value those professionals who enhance this proximity: Yes, there's a nurse who, as soon as she starts her shift, comes here to ask me, I don't know, she's very concerned with me, I like that, I like it that she comes here to ask me how I am doing (E19, 30). One fundamental aspect in the children's perception is the degree of understanding they feel in the interaction. They gradually evaluate the treatment they receive: greeting, questions, support and comfort granted. Moreover, for the children, the signs of affect are related with the bodily expressions and non-verbal language the nursing staff uses during therapeutic interventions. According to them, these are manifestations that make them feel acknowledged and appreciated: The thing is that I'm always the same, I'm super well, each time the nurses come I cheer up a lot because they spoil me a lot, it's always 
the same $(E 10,35)$. When they consider that the adults are close, the minors create affective bonds easily. One way of expressing proximity and affect for the children is when they let them know that they felt well with regard to their presence at the hospital: Well, they want me to stay. They tell me stay with us. They feel pity when I tell them that I might go. They do not want me to go (E5,57). Through this kind of phrases, the nursing professional makes it clear to the child that a bond of friendship exists. The expression stay with us is used to transmit a feeling of filiation, of affection and belonging to the place where the child is receiving care.

Similarly, the children know that they will be rewarded with the nursing professionals' empathy and affection when they have behaved well during different interventions. When they did the test, they told me that I behaved well, that I did it very well. Because it's always the same, when they tell me that I'll do fine, they really encourage me (E17, 34). In this sense, if the nursing professionals perceive that the child has assimilated the recommendations and behaved as expected, they use expressions of encouragement, sometimes accompanied by affectionate signs like a kiss or a caress. All of these gestures clearly cheer up the minors, showing themselves pleased and receptive towards the interaction.

\section{Signs of interest}

The minors express that nursing professionals also demonstrate their interest when they pay attention to their recreation and entertainment at the hospital: They ask me: What about going to the hospital school, they also asked me if I wanted to get up. I said yes, and when they finished with the dressing, they helped me and I went to the hospital school $(E 22,12)$. When the nursing staff briefly and spontaneously gets immersed in the way they recreate their daily reality in the hospital, the children see this as a good memory of their hospital stay: And the nurses and everyone went to my room and sang happy birthday for me and gave me presents $(E 15,23)$. These approaches enhance the children's view of an approximation with their routines and their affective components, likings, entertainment and particularly their experience of the disease and hospitalization.

Valuation of nursing actions. Sympathetic nurse

During the interviews, children who are bordering on or going through pre-adolescence/adolescence highlight the character of the nursing professional, especially because of his/her sympathy. They relate it with compliments made regarding their physical aspect or the qualities they highlight in the minor. When one tells children that they are beautiful, intelligent, their ideas about the level of personal acceptance are reinforced, about how pleasant their presence is and about how important their personal qualities are for other people. This allows them to feel well about themselves and secure in interpersonal relations: What I liked best at the hospital are the nurses. Yes, they are very sympathetic, there are two of them who tell me "that I'm very pretty" and come and visit me to see how I'm doing $(\mathrm{E} 6,34)$. Moreover, the children know when one professional is more sympathetic than another. They distinguish this through that person's attitudes in care: I like nurse Milena best, she makes me laugh and takes most care when doing everything, she's respectful, likeable, affectionate and educated $(E 8,31)$. They also consider that the nursing professionals are sympathetic and likeable when they take care when expressing themselves about the medical diagnosis and help them decrease their anxiety through words: They are all very likeable. They tell me everything very delicately. They inform me that what I have is not, oh, I don't know how to tell you, that it's not severe, that I don't have to feel bad and that makes me feel good $(\mathrm{E9}, 42)$. The reports prove that the transmission of ethical and human values plays a fundamental role in the child's perception of nursing care.

Valuation of nursing actions. "Bad mood nurse"

The children continuously qualify the nursing professionals' behaviors. Therefore, it is not rare that they highlight the less favorable attitudes they perceive in treatment and care delivery. In their language, the children use the term "bad-mood" to designate those issues they do not agree with: There's one really badtempered one, who told my father that I wouldn't get up anymore, she's all displeased $(E 5,45)$. The fact that the children qualify the professionals' relational attitude as negative has to do with the way they respond to their requests, when they do not value their needs, or when the children perceive no willingness to cooperate: They got angry because the doctor, when he finishes seeing everyone, he comes to see me, a bit late already. And, my mother goes there and asks and, once, they got irritated. They got offended when she went to ask for the doctor. They do not ask how I'm feeling when the doctor doesn't come $(\mathrm{E} 13,51)$. One aspect that is fundamental for the children is to feel that the accompanying adults who represent authority respect them. In this sense, the child needs to understand the intentionality of nursing actions through explanations and solid arguments. 


\section{Discussion}

As observed in the study findings, children's adaptation to hospitalization not only depends on their psychosocial, cultural and biological conditions, but also on their understanding about the experience according to their cognitive referents. To the extent that children increase their cognitive and abstractive abilities, they register all of their experiences more truthfully and these positive or negative aspects interfere in their learning(18). Thus, effective communication between children's and nursing staff is characterized as a balance between effective (causing a positive effect) and neutral behaviors (causing a neutral effect). The behaviors the nursing professionals adopt should integrate emotional care with effective information ${ }^{(19)}$. Children present feedback facilities, which is why it is easy to observe that they manifest their needs and demands when dialoging with adults. This feedback process helps the children to reorganize their ideas and grants coherence to what they think. In conversations, this helps them gain confidence and security and, thus, they are capable of giving effective responses in function of their understanding of the message(20).

It should be acknowledged that, while the children's cognitive skills develop with age, feelings of sympathy and role-taking increase. In this sense, as observed in the reports about the valuation of the nursing staff's behavior, as they children distinguish the sense of their own and other people's identity, their empathic feelings become more sophisticated, they further consider other people's actions towards them and can establish a clearer idea of adult people's behaviors ${ }^{(21)}$.

Some studies ${ }^{(22-23)}$ affirm that, through their professional practice, nursing professionals have developed personal skills and empathy strategies to manage to influence the children's and their families' experiences. The researchers consider, however, that these strategies need to be analyzed in depth and that, as a part of nursing work organization, periodical assessment of their results is needed. This would permit further knowledge on the children's responses towards certain verbal and non-verbal stimuli, so as not to mix up information transmission, adapted to the children's conditions (age, diagnosis, particular circumstances) with the form of interacting.

Thus, the present research results support findings in other studies that appoint the need to generate strategies that help to enhance communicative interaction with children and their families. This communication permits knowing their needs, understanding their situation and undertaking educative actions that influence the children's and their families' emotional conditions. IF children perceive nurse-family interaction positively, they get more cheerful, enhancing theirs and their families' psychosocial wellbeing during hospitalization(24).

\section{Conclusions}

The children positively value nursing care at the hospital and acknowledge that the interaction with care professionals contains a range of affective and social contents. The communication established with children plays a fundamental role in the mediation of their experiences and in the ideas they elaborate about the health-disease process. Further qualitative research is needed, in which nursing professionals can reassess their relational strategies and discourse, allowing them to determine the importance of improving their interpersonal skills, especially empathy. This type of studies would permit questioning and confronting the nursing discourse itself, leading to the promotion of more correct behaviors in view of the children's and their relatives' demands.

\section{References}

1. McGilton K, Irwin-Robinson H, Boscart V, Spanjevic L. Communication enhancement: nurse and patient satisfaction outcomes in a complex continuing care facility. J Adv Nurs. 2006;54(1):35-44.

2. Aujoulat I, Simonelli F, Decache A. Health promotion needs of children and adolescent in hospitals: A review. Patient Educ Counsel.2006;61:23-32.

3. Schimidt C, Bernaix L, Koski A, Weese J, Chiappetta M. Hospitalized children's perceptions of nurses and nurse behaviors. Am J Matern Child Nurs. 2007;32(6):336-42.

4. Silveira AO, Angelo M. A experiência de interação da família que vivencia a doença e hospitalização da criança Rev. Latino-Am. Enfermagem 2006;14(6):893-900.

5. Mikkelsen G, Frederiksen K. Family-centred care of children in hospital- a concept analysis. J Adv Nurs. 2011;67(5):1152-62.

6. Coyne I. Consultation with children in hospital: children, parents and nurses perspectives. J Clin Nurs. 2006;15:61-71.

7. Mello DF, Lima RAG. Êxito técnico, sucesso prático e sabedoria prática: bases conceituais hermenêuticas para o cuidado de enfermagem à criança. Rev. LatinoAm. Enfermagem. 2009;17(4):580-5. 
8. Pons X. La aportación a la psicología social del interaccionismo simbólico: una revisión histórica. EduPsyké. 2010;9(1):23-41.

9. Kemppainen JK. The critical incident technique and nursing care quality research. J Adv Nurs. 2000;32(5):1264-71.

10. Fitzgerald K, Saele S, Kevins C, McElvaney R. The critical incident technique: a useful tool for conducting qualitative research. J Dent Educ.2008;72(3):299-304.

11. Cornejo M, Salas N. Rigor y calidad metodológicos: un reto a la investigación social cualitativa. Psicoperspectivas. 2011;10(2):12-34.

12. Roberts CA. Unaccompanied hospitalized children: a review of the literature an incidence study. J Pediatr Nurs. 2010;25:470-6.

13. Dulmen S. Pediatric-parent-child communication Problem -related or not? Patient Educ Couns. 2002;52(1):61-8.

14. Pinheiro $M E$, Silva $M J$, Angelo $M$, Ribeiro CA. O significado da interação das profissionais de enfermagem com o recém-nascido/família durante a hospitalização. Rev. Latino-Am. Enfermagem. 2008;16(6):1012-8.

15. Carbelo B, Jáuregui E. Emociones positivas: Humor positivo. Papeles Psicólogo. 2006;27(1):18-30.

16. Buxman K. Humor in the OR: a stitch in time? AORN J. 2008;88(1):67-77.

17. Papalia D. Psicología del Desarrollo. $11^{\circ}$ ed. México: McGraw-Hill; 2009.

18. Koopman H M, Baars R M, Chaplin J, Zwinderman K H. Illness through the eyes of the child: the development of children's understanding of the causes of illness. Patient Educ Couns. 2004;55(3):363-70.

19. Shin $H$, White-Traut R. Nurse-child interaction on an inpatient paediatric unit. J Adv Nurs. 2005;52(1):56-62. 20. Noreña AL, Cibanal L. El contexto de la interacción comunicativa. Factores que influyen en la comunicación entre los profesionales de enfermería y los niños hospitalizados. Cultura de los Cuidados: Rev Enferm Humanidades. 2008;12(23):70-9.

21. Lindeke L, Nakai M, Johnson L. Capturing children's voices for quality improvement. Am J Matern Child Nurs. 2006;31(5):290-5.

22. Robinson S. Children and young people's views of health professionals in England. J Child Health Care. 2010;14(4):310-26.

23. Wilson ME, Megel ME, Enenbach L, Carlson KL. The voices of the children: Stories about hospitalization. J Pediatr Healthcare. 2010;24(2):95-102.

24. Coyne I. Children's experiences of hospitalization. J

Received: Mar. 21 2011

Child Health Care. 2006;10(4):326-36.

Accepted: Sept. $20^{\text {th }} 2011$ 